\section{Adapting the New Normal Teaching Strategies as a Coping Mechanism for Dental Students}

Sir,

The current COVID-19 pandemic has jeopardised various aspects of patient care and training of dental professionals thus impelling the dental schools to adopt Emergency Remote Teaching (ERT). Dental schools around the Globe have adopted various innovative virtual communication technology to facilitate dental students and patients. ${ }^{1}$ Currently available smart devices and various online learning platforms and applications have made it possible for students to listen, learn, and interact with the faculty members. ${ }^{2}$ However, it remains challenging to balance the educational needs of students and ensure operator-patient safety while delivering patient care. ${ }^{3}$

Many dental schools have completely switched to ERT for theoretical teaching and postponed the clinical training on patients until return to normalcy; while some dental schools allowed only laboratory preclinical simulation activities with strict physical distancing measures. ${ }^{4}$ Currently, theory lectures, case studies, $\mathrm{CBL}, \mathrm{PBL}$, and journal clubs are being conducted either in the form of live interactive or recorded sessions by the faculty members.

Dental students, particularly in the clinical years, experience significantly higher levels of stress-related to their academic and clinical uncertainties due to the current COVID-19 outbreak. ${ }^{5}$ Additionally, dental professionals have a greater vulnerability of exposure to the SARS-CoV-2 owing to the nature of the dental treatment procedures, , which in turn, has created a significant fear among the students, thus predisposing them to high levels of anxiety and depression. These prolonged high levels of stress from academic and non-academic related concerns may lead to mental and physical disability, if they are not identified in the early stages. ${ }^{6}$

Despite the various measures inculcated by the dental schools to mitigate the challenges posed by the pandemic, a significant number of dental students particularly clinical year students experience stress, anxiety, and depression due to the future uncertainties. Therefore, it is imperative to adopt the new normal teaching strategies that not only facilitate the smooth conduction ofERT, butalso serve as a coping mechanism to overcome these stressful conditions and provide an appropriate psychological support for the students.

In order to identify and address the students' concerns during this pandemic, we at Faculty of Dentistry, SEGi University, Malaysia, has conducted online staff-student consultative sessions, wherein each student has the opportunity to ex- press their feedback regarding the academic and non-academic related issues. These students' concerns were categorised into academic, clinical, personal, and accommodation-related. We also practise the system of year coordinator, and mentor-mentee programme, to address their personal and professional problems. The year coordinators facilitate the academic and clinical activities for each year, which includes, scheduling of online classes, preclinical sessions, and disseminates the current updates on the COVID-19. They also regularly engage them in live online sessions to update their academic schedule, online examination, marking system, and completion of the minimal clinical requirement (MCE), particularly for the final year students to address their academic and clinical related fear and anxiety among the students. We also encourage them to practise self-learning, make full use of available online resources, and learn about the latest academic developments. For effective utilization of available time, we also introduced an online Guided self-directed learning by giving the real-life scenarios through online learning management system "Blackboard". This allowed the students to take guidance from the teachers to search the credible literature to solve the cases. Furthermore, we introduced online peer assisted learning which facilitated the interaction among the senior students and students of the same academic year.

Dentistry, primarily being a clinically orientated course, so we have allowed the final year students to work on patients to achieve minimal clinical requirement before their graduation by adhering to the strict standard operating procedures (SOPs) and guidelines for dental practice during this pandemic, thus reducing the fear of cross-infection by the doctor-patient interaction. Furthermore, the annual professional examinations were restructured for online assessments to prevent the delay in the graduation and beginning of the next academic year, which also was a fear predominately among the final year students.

We have also restructured and implemented the e-mentoring programme to provide constant consultative sessions to address the various concerns posed by the vicissitude pandemic situation. Mentor-mentee sessions allow the individual students to discuss their academic and non-academic matters, including personal problems such as financial and accommodation-related issues, with their mentor. The mentor acts as a guide, facilitator, and provides the appropriate counselling to each mentee, thus promoting the overall personal development of the students. Additionally, students requiring psychological support were referred to the qualified counsellor who has been appointed by the university to provide appropriate psychological support to them.

These collective efforts, taken at our faculty, not only facilitate the constant interaction, and encouragement to the students, but also provides appropriate counselling thereby circumventing the negative academic and psychological outcomes. 


\section{ACKNOWLEDGEMENT:}

We would like to thank our Dean, Faculty of Dentistry, SEGi university, Malaysia for giving the valuable suggestions and for final approval of the manuscript.

\section{CONFLICT OF INTEREST:}

The authors declared no conflict of interest.

\section{AUTHORS' CONTRIBUTION:}

SKV, SY: Involved in drafting and final approval of the manuscript.

\section{REFERENCES}

1. Ghani F. Corona virus disease - 2019 (COVID-19) - Planning for emergency dental practice and dental education. Acta Sci Dent Sci 2020; 4(7):16-21.

2. Ghani F. Remote teaching and supervision of graduate scholars in the unprecedented and testing times. J Pakistan Dental Association 2020; 29 (Covid-19 Special Issue):36-42. doi.org/10.25301/JPDA.29S.S36

3. Ghani F. Covid-19 Outbreak - Immediate and long-term impacts on the dental profession. Pak J Med Sci 2020; 36(COVID19-S4):COVID19-S126-S9. doi: http://doi.org/ 10.12669/pjms.

4. Anderson ML, Turbow S, Willgerodt MA, Ruhnke GW. Education in a crisis: The opportunity of our lives. J Hosp
Med 2020; 15(5):287-91. doi: 10.12788/jhm.3431.

5. Ahmed MA, Jouhar R, Ahmed N, Adnan S, Aftab M, Zafar MS, et al. Fear and practice modifications among dentists to combat novel coronavirus disease (COVID-19) Outbreak. Int J Environ Res Public Health 2020; 17(8):2821. doi: 10.3390/ijerph17082821.

6. Basudan S, Binanzan N, Alhassan A. Depression, anxiety and stress in dental students. Int J Med Educ 2017; 8:17986. doi: 10.5116/ijme.5910.b961.

Suresh Kandagal Veerabhadrappa and Seema Yadav

Faculty of Dentistry, SEGi University, No. 9 Jalan Teknologi, Taman Sains, Petaling Jaya, Kota Damansara, Selangor, Malaysia

Correspondence to: Dr. Suresh Kandagal Veerabhadrappa, Faculty of Dentistry, SEGi University, No. 9 Jalan Teknologi, Taman Sains, Petaling Jaya, Kota Damansara, Selangor-47810, Malaysia

E-mail:dr.suri88@gmail.com

Received: June 29, 2020; Revised: September 02, 2020; Accepted: November 12, 2020

DOI: https://doi.org/10.29271/jcpsp.2021.05.608 